(C) 2013

Одарюк О. О., аспірант *

Полтавська державна аграрна академія

\title{
ЕКОНОМІКО-ПРАВОВЕ РЕГУЛЮВАННЯ РИНКУ ЗЕМЕЛЬ СІЛЬСЬКОГОСПОДАРСЬКОГО ВИКОРИСТАННЯ
}

\section{Рецензент - доктор сільськогосподарських наук, професор М. Я. Шевніков}

\begin{abstract}
Визначено проблеми та особливості формування ринку земель. Розглянуто сутність $i$ значення державного впливу на нього, економіко-правові важелі регулювання. Проаналізовано ситуацію у галузі здійснення контролю за використанням та охороною земель. Заплановані держані заходи щзодо вдосконалення системи контролю за використанням земель сільськогосподарського призначення. Розглянуто особливості становлення ринку землі, виділено основні проблеми його розвитку, запропоновано шляхи їх подолання й оптимізаиії у сучасних ринкових відносинах.
\end{abstract}

Ключові слова: ринок земель, економічне регулювання, ринкові відносини, земельний банк.

Постановка проблеми. Земельна реформа в Україні одна з чи не найважливіших реформ за період незалежності нашої держави, адже земля $є$ стратегічним ресурсом країни. Ринкові перетворення в аграрному секторі економіки призвели до радикальних змін у формах власності на землю та земельних відносинах, які зумовили включення землі в ринковий обіг і поступове формування ринку сільськогосподарських земель. Стан земельних ресурсів та ефективність їх використання визначають результативність функціонування як сільськогосподарського формування, так і аграрної галузі у цілому, є основою продовольчої безпеки держави. Протягом останніх років розвиток аграрного сектора економіки України супроводжувався посиленим використанням наявних сільськогосподарських угідь, деградацією земель і навіть повною їх втратою. Тому питання ефективності використання сільськогосподарських земель та екологобезпечного функціонування земельного ринку в Україні нині особливо актуальні.

Аналіз останніх досліджень і публікацій, у яких започатковано розв'язання проблеми. Обгрунтуванню значення й місця раціонального використання земельних ресурсів у системі соціально-економічного розвитку країни присвячено значну кількість наукових праць вітчизняних учених, таких як Д. С. Добряк, П. Т. Саблук,
I. Ф. Томич, М. А. Хвесик, О. М. Царенко та інші. Ще з початку земельної реформи вони почали висловлювати свої думки про необхідність ринку землі, його сучасний стан та перспективи розвитку, обговорювати актуальні питання функціонування й законодавчого забезпечення земельного ринку. На їх думку, у системі господарювання сегментом повинен бути ринок землі, в іншому випадку не буде ринкової системи як такої [2]. Разом із тим не висвітленими залишаються проблеми економічного регулювання раціонального землекористування, розробка ефективних його механізмів тощо.

Мета дослідження: розмежувати вплив факторів на економічну стійкість земельних відносин та ринку землі.

Завдання дослідження:

- визначити особливості земельних відносин в аграрному секторі економіки України в період реформування (1999-2012 років);

- розглянути проблеми створення системи економічних важелів регулювання земельних відносин у контексті ринкових перетворень.

Матеріали та методи дослідження. Досліджено розвиток ринкових відносин, що об'єктивно передбачає залучення землі у ринковий обіг, розвиток земельного ринку. Без ринку земель неможливі успішна підприємницька діяльність, підвищення ефективності аграрного виробництва, продовольча безпека держави та екологобезпечне використання земельних ресурсів.

Результати дослідження. Ринок земель ми розглядаємо як еколого-економічне поняття, поскільки раціональне використання останніх має на меті досягнення економічного ефекту 3 одночасним збереженням і поліпшенням земель у процесі їх використання. Ринок земель - це особлива сфера товарної економіки, в якій виникають економічні відносини 3 приводу купівлі-продажу, застави, оренди та обміну землі, що спрямовані на ефективну господарську діяльність і використання цього ресурсу з погляду екологічної безпеки.

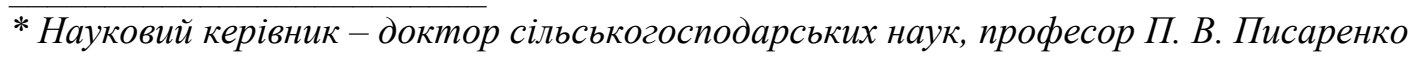


Умовами ефективного функціонування ринку сільськогосподарських земель $є$ :

- створення широкого нормативно-правового поля;

- формування конкурентного середовища;

- наявність платоспроможного попиту на землю;

- поява мотивації виходу на земельний ринок продавців земельних ділянок;

- ефективна система ціноутворення на землю;

- створення спеціалізованої інфраструктури ринку земель (Земельний банк, інформаційні, консультаційні та посередницькі структури, страхові компанії тощо);

- наявність контролю над ринком земель із боку держави, яка регулює перерозподіл земель, контролює їх використання за цільовим призначенням, установлює розміри приватного землеволодіння;

- наявність землевласників, спроможних раціонально використовувати землю й ефективно господарювати;

- дійова система захисту землевласників і землекористувачів [3].

Ці умови визначають зрілість та ефективність функціонування земельного ринку.

Однак у процесі переходу аграрного сектора економіки до ринкових відносин водночас із правовими набувають актуальності питання економічного стимулювання раціонального використання земельно-ресурсного потенціалу, що часто не відповідає параметрам раціонального природокористування. Як наслідок - погіршуються фізичні й хімічні властивості грунтів, зростають площі земель, забруднених атмосферними викидами та стічними водами, хімічними речовинами й радіонуклідами, змитих та дефляційно небезпечних земель, значні площі займають кислі, засолені та солонцюваті грунти. За таких тенденцій сільське господарство через недобір урожаю втрачатиме щорічно лише зерна 8-9 млн тонн [1]. Окрім того рік у рік зменшуються обсяги робіт щодо поліпшення хімічного стану грунтів.

Механізм економічного регулювання земельних відносин - це система заходів економічного впливу, спрямованих на реалізацію земельної політики держави, забезпечення прав землевласників і землекористувачів, установлення соціально справедливих платежів за землю, економічне стимулювання раціонального й ефективного землекористування, введення економічних санкцій за нераціональне використання та погіршення екологічного стану земельних ділянок, а також на захист земель сільськогосподарського призначення від виснаження, зниження родючо- сті грунтів [1].

Принципами механізму економічного регулювання земельних відносин $\epsilon$ :

- вибір критерію оціночного показника для грошової оцінки сільськогосподарських земель;

- проведення грошової оцінки сільськогосподарських угідь на базі їхньої економічної оцінки;

- опрацювання підходів і критеріїв стосовно визначення розмірів земельного податку; впровадження державного регулювання земельного обігу та законодавче врегулювання ринку земель;

- застосування економічного стимулювання за раціональне використання земель;

- уведення економічних санкцій за порушення законодавства щодо використання земель [3].

Критеріями економічного стимулювання власників землі й землекористувачів $€$ відтворення i підвищення родючості грунтів.

За даними П. Т. Саблука, головними принципами економічного стимулювання $\epsilon$ :

- здійснення стимулювання за результатами впроваджених заходів щодо підвищення родючості грунтів й охорони земель;

- стимулювання залежно від обсягів і результатів реалізації заходів щодо забезпечення раціонального використання земель, об'єктивності визначення розмірів стимулів від кадастрової оцінки земель [2].

Економічне стимулювання за раціональне використання земель здійснюється шляхом:

- повної або часткової компенсації витрат, спрямованих на поліпшення якості грунтів;

- зниження ставок земельного податку за землі, що знаходяться у приватній власності громадян або користуванні господарств;

- тимчасового звільнення від плати за земельні ділянки, на яких проведено заходи щодо поліпшення якості грунтів й охорони земель за власний рахунок;

- звільнення від плати за земельні ділянки, що перебувають у стані сільськогосподарського освоєння; надання пільгових кредитів і цільових субсидій;

- безплатної передачі господарствам техніки, добрив, транспортних засобів та інших матеріальних цінностей;

- часткової компенсації зниження доходів у результаті консервації еродованих і забруднених ділянок не з вини суб'єктів господарювання [1].

Відповідно до статті 205 Земельного кодексу України, економічне стимулювання раціонального використання земель включає:

- надання податкових і кредитних пільг громадянам та юридичним особам, які здійснюють 


\section{СТОРІНКА МОЛОДОГО ВЧЕНОГО}

за власні кошти заходи, передбачені загальнодержавними і регіональними програмами використання й охорони земель;

- виділення коштів державного або місцевого бюджету громадянам та юридичним особам для відновлення попереднього стану земель, порушених не з їхньої вини;

- звільнення від плати за земельні ділянки, що перебувають у стадії сільськогосподарського освоєння або поліпшення їхнього стану згідно 3 державними та регіональними програмами;

- компенсацію $з$ бюджетних коштів зниження доходу власників землі та землекористувачів унаслідок тимчасової консервації деградованих і малопродуктивних земель, що стали такими не 3 їхньої вини [2].

До економічного стимулювання власників землі та землекористувачів за раціональне використання земель залучаються кошти державного i місцевого бюджетів, що надійшли від плати за землю, компенсаційних платежів у разі вилученні сільськогосподарських угідь для потреб промисловості та інших несільськогосподарських цілей, а також кредитні ресурси державних і комерційних банків.

В основу розрахунків конкретних розмірів стимулів за підвищення родючості сільськогосподарських угідь покладається певний відсоток грошової оцінки земельної ділянки, на якій здійснювалось поліпшення, залежно від зміни інтегрального показника еколого-агрохімічної характеристики грунтів чергового обстеження, порівняно $з$ попереднім, за матеріалами екологоагрохімічної паспортизації полів і земельних ділянок, що проводиться за спеціальною методикою.

Виконання протиерозійних заходів на земельних ділянках суб'єктами господарювання за власні кошти повністю компенсується державою. Компенсація агротехнічних заходів, проведених землевласниками і землекористувачами для поліпшення якісного стану грунтів, здійснюється диференційовано, залежно від зміни показників якості грунтів, відображених в агрохімічному паспорті (від 30 до 100 \% витрат на проведення цих заходів) [3].

Організацію робіт 3 економічного стимулювання за раціональне використання земель сільськогосподарського призначення здійснює спеціальна комісія, створена районною державною адміністрацією.

Клопотання щодо економічного стимулювання порушують власники землі й землекористувачі, якими проведено заходи, спрямовані на поліпшення якості земель та їхньої охорони, на підставі результатів агрохімічного обстеження земель.

Економічне стимулювання суб'єктів господарювання може бути дійовим інструментом в удосконаленні економічного механізму регулювання земельних відносин і раціональному використанні земельно-ресурсного потенціалу. Один iз важелів економічного стимулювання - податковий, тобто зниження податкових ставок, податкових відрахувань та кредитів [3].

Згідно зі статтею 302 Податкового кодексу України, для сільськогосподарських товаровиробників платників фіксованого сільськогосподарського податку об'єктом оподаткування $\epsilon$ площа сільськогосподарських угідь (ріллі, сіножатей, пасовищ і багаторічних насаджень) та земель водного фонду (внутрішніх водойм, озер, ставків, водосховищ), що перебуває у власності сільськогосподарського товаровиробника або надана йому в користування, у тому числі на умовах оренди.

Щодо загального оподаткування, то, відповідно до п. 14.1 .72 статті 14 згаданого Кодексу, земельний податок - обов'язковий платіж, що справляється 3 власників земельних ділянок i земельних часток (паїв), а також постійних землекористувачів. Так, у п. 4.1.147. статті 14 сказано, що плата за землю - загальнодержавний податок, який справляється у формі земельного податку та орендної плати за земельні ділянки державної й комунальної власності. Отже, згідно 3 положеннями Податкового кодексу України, поняття «плата за землю» $\epsilon$ узагальнюючим i поєднує два обов'язкових платежі - земельний податок та орендну плату за землі державної й комунальної власності. Доцільно зазначити, що податкова система в сільському господарстві не забезпечила раціонального використання земельно-ресурсного потенціалу, тому пї потрібно вдосконалювати, а основний стратегічний вектор спрямовувати до раціонального землекористування.

Податкове законодавство України, передбачаючи 28 видів загальнодержавних податків i зборів (ст. 14 Закону України «Про систему оподаткування») й 14 видів місцевих податків і зборів (ст. 15 цього Закону), встановлює лише незначні пільги щодо сплати податку на прибуток підприємств та пільги по платі за землю, що за певних умов можуть використовуватися особами, які здійснюють заходи щодо охорони земель.

На даний час законодавство не передбачає механізму пільгового кредитування громадян та юридичних осіб, які здійснюють за власні кошти 
заходи, передбачені загальнодержавними і регіональними програмами використання та охорони земель.

Висновок. Формування ринку земель в аграрному секторі України - закономірне явище й у перспективі необхідне, але може спричинити зниження рівня екологічної та соціальної відповідальності землекористувачів. Найдієвішими важелями впливу на екологічно обгрунтовану господарську діяльність землекористувачів $\epsilon$ економічні, зокрема закріплені на законодавчо-

\section{БІБЛІОГРАФІЯ}

1. Дорогунцов С. I. Оцінка земельно-ресурсного потенціалу України і проблеми забезпечення його ефективного використання / С. І. Дорогунцов, О. С. Новоторов, Т. С. Ніколаєнко. - К. : НАН України, РВПС України, 2009. - 82 с.

2. Саблук П. Т. Розвиток земельних відносин в му рівні податкові пільги за раціональне землекористування.

Разом із тим проведення значних обсягів землевпорядних робіт на етапі здійснення земельної реформи потребують відповідного фінансування, а відсутність коштів робить це проблематичним. Механізм реалізації основних вимог реформування земельних відносин у встановлені терміни потребує фінансування як із боку держави, так і самих землекористувачів.

Україні / П. Т. Саблук. - К. : ННЦ «Інститут аграрної економіки», 2010. - $396 \mathrm{c}$.

3. Кулик В. М. Попередні підсумки та прогноз соціально-економічних і екологічних результатів земельної реформи / В. М. Кулик // Землевпорядний вісник. - 2007. - № 1. - С. 45-50. 